\title{
BENTUK MATA PENCAHARIAN MASYARAKAT PENDUKUNG SITUS GUNUNG SROBU (Prehistory Livelihood in the Srobu Site)
}

\author{
Erlin Novita Idje Djami \\ Balai Arkeologi Jayapura, Jalan Isele, Kampung Waena, Jayapura 99358 \\ Telepon (0967) 572467, Faksimile (0967) 572467, e-mail: novita_idje@yahoo.co.id
}

\section{INFO ARTIKEL}

\section{Histori artikel:}

Diterima 8 April 2015

Direvisi 27 April 2015

Disetujui 4 Oktober 2015

\section{Keywords:}

livelihood,

material Cultural,

Gunung Srobu Site

Kata kunci:

mata pencaharian,

materi budaya,

situs Gunung Srobu

\begin{abstract}
Research on the form of the people's livelihood support Gunung Srobu sites is very important. This research aims to determine the extent of the development of human knowledge and ability to face the challenges of the natural environment to maintain the existence of the community, as well as expertise in generating technology equipment. Since the public support for culture Gunung Srobu Site does not exist any longer, so the study of forms of livelihood can be done through cultural material remnants preserved their activities. This study uses a qualitative approach to the form of inductive reasoning, while strategies are applied through literature and field observations. All the data collected in this study is then processed by indentifying by type and analyzed qualitative description that aims to know the meaning or interpret the empirical reality that the objects contained in the study. The results of this study are in the form of various types of artifacts such as pottery, stone tools, tool shells, animal bone remains, and shells litter. Culture material is closely related to the public livelihood support form Gunung Srobu site namely horticulture, hunting, gathering fishing, farming, and industry.
\end{abstract}

\begin{abstract}
Abstrak
Penelitian tentang bentuk matapencaharian masyarakat pendukung situs Gunung Srobu sangat penting dilakukan. Penelitian ini bertujuan untuk mengetahui perkembangan pengetahuan manusia dan kemampuannya dalam menghadapi tantangan lingkungan alam demi mempertahankan eksistensi komunitasnya, serta kemahirannya dalam menghasilkan teknologi peralatan hidup. Karena masyarakat pendukung budaya situs Gunung Srobu sudah tidak ada, maka kajian tentang bentuk matapencahariannya dapat dilakukan melalui kajian terhadap materi budaya sisa-sisa aktivitasnya yang terawetkan. Penelitian ini menggunakan metode pendekatan kualitatif dengan bentuk penalaran induktif, sedangkan strategi pengumpulan data dilakukan melalui studi pustaka dan observasi di lapangan. Semua data yang berhasil dihimpun dalam penelitian ini kemudian diolah dengan mengidentifikasi berdasarkan jenisnya dan kemudian dianalisis deskriptif kualitatif untuk memahami makna atau menafsirkan realitas empiris yang terkandung pada objek-objek kajian. Penelitian ini berhasil menemukan beragam jenis artefak seperti tembikar, alat batu, alat kerang, sisa tulang binatang, dan sampah kerang. Materi-materi budaya tersebut berkaitan erat dengan bentuk matapencaharian masyarakat pendukung situs Gunung Srobu yaitu bercocoktanam, berburu, meramu, nelayan, beternak, dan industri.
\end{abstract}

\section{PENDAHULUAN}

Kehidupan masa prasejarah memang telah berlalu, namun demikian gambaran tentang kehidupan manusia di masa itu, masih dapat diketahui melalui kajian terhadap materi-materi budaya yang terawetkan dan terwariskan hingga kini. Salah satu kajian yang cukup menarik tentang kehidupan manusia masa lampau terkait bentuk matapencaharian hidupnya. Karena itu, bentuk-bentuk matapencaharian pada masyarakat pendukung budaya di Situs Gunung
Srobu juga merupakan fenomena yang menarik untuk diungkap.

Situs Gunung Srobu merupakan temuan baru yang diketahui keberadaannya tahun 2014. Situs ini terletak di sebuah tanjung, kawasan Teluk Youtefa, Kelurahan Abe Pantai, Distrik Abepura, Kota Jayapura. Penelitian arkeologi di situs tersebut telah berhasil menemukan sejumlah materi budaya yang cukup beragam jenisnya, seperti gerabah, alat serpih, kapak batu, kapak lonjong, batu 
asah, batu pipisan, gandik, alat kerang, sisa tulang binatang, sisa tulang manusia, sampah kerang, arang serta fondasi bangunan dan tinggalan budaya tradisi megalitik (Tim Peneliti, 2014: 8-39). Temuan-temuan tersebut ada yang masih utuh, sebagian besar berbentuk fragmentaris. Keberadaan data primer maupun sumber informasi penting lainnya yang ditemukan dapat menggambarkan kembali berbagai aspek kehidupan manusia pendukung situs Gunung Srobu di masa lampau.

Salah satu bentuk aktivitas manusia masa lampau di Situs Gunung Srobu yang menarik untuk dikaji lebih jauh adalah tentang bentuk matapencaharian hidup masyarakat pendukungnya. Untuk mengungkapkan kehidupan masa lampau dilakukan melalui kajian terhadap temuan-temuan materi budaya yang terawetkan, khususnya berkaitan dengan bentuk aktivitas dalam suatu sistem matapencaharian. Dari penelitian ini terungkap bentuk-bentuk matapencaharian hidup masyarakat pendukung budaya situs Gunung Srobu, dan bahkan diketahui pula jenis-jenis tinggalan budayanya. Kajian yang juga tidak kalah pentingnya dilakukan berkaitan dengan konteks lingkungan sekitar situs sebagai faktor utama yang mempengaruhi, baik alam-pikir maupun bentuk pola tingkah laku manusianya.

Berbicara tentang matapencaharian, tentunya tidak terlepas dari peran manusia sebagai makhluk hidup yang berbudaya dan memiliki kebutuhan bersifat hayati dan manusiawi. Manusia hidup dari unsur-unsur lingkungannya, misalnya udara untuk pernafasan, air untuk minum dan keperluan sehari-hari, tumbuhan dan hewan untuk makan serta lahan untuk tempat tinggal (Vita, 2004: 25-26). Demikian pula kehidupan manusia di muka bumi ini juga berada dalam suatu kerangka budaya tertentu. Eksistensi manusia juga dituntut dapat hidup layak dan manusiawi. Untuk itu, manusia telah mempelajari bagaimana memanfaatkan sumber daya alam yang ada di muka bumi, dan dengan kebudayaannya juga mampu menciptakan suatu bentuk lingkungan tertentu (Purwanto, 2008: 164-166), serta mampu mengadaptasikan diri dengan lingkungannya sehingga ia tetap mampu melangsungkan kehidupannya (Tax, 1953: 243 dalam Purwanto, 2008: 166). Sehubungan dengan pernyataan-pernyataan tersebut di atas, bagaimana dengan bentuk matapencaharian pada masyarakat pendukung budaya situs Gunung Srobu dalam usaha mempertahankan hidup dan kehidupannya.

Penelitian di situs Gunung Srobu sudah pernah dilakukan. Dalam penelitian sebelumnya hanya terbatas pada pengungkapkan berbagai bentuk materi budaya (fragmen gerabah hias dan polos, cangkang moluska, alat batu berupa alat serpih, kapak batu, fragmen kapak lonjong, gandik, pipisan alat kerang, struktur lantai rumah, batu inti, batu asah, bangunan megalitik dan fragmen tulang) dan fungsi-fungsinya (Tim Peneliti, 2014: 8-39). Sedangkan penelitian yang dilakukan di Situs Gunung Srobu dalam tulisan ini akan mengungkapkan tentang bentukbentuk matapencaharian masyarakat 
pendukungnya, berdasarkan temuan materi budaya dan lingkungan sekitarnya.

\section{METODE PENELITIAN}

Penelitian ini menggunakan metode berpendekatan kualitatif dengan penalaran induktif. Metode ini mengemukakan data dari kasuskasus diperoleh di lapangan kemudian dianalisis atau dibahas secara mendalam terkait dengan berbagai aspek yang melingkupinya sehingga dapat ditarik beberapa kesimpulan secara umum. Sedangkan strategi dalam penelitian ini dilakukan melalui beberapa tahap, yaitu:

1. Tahap pengumpulan data melalui studi pustaka, dengan melakukan kajian terhadap beberapa pustaka yang dianggap relevan dengan objek kajian, dan observasi langsung di lapangan terhadap objek kajian maupun lingkungan sekitarnya.

2. Tahap pengolahan data diawali dengan melakukan identifikasi data temuan lapangan yang berhubungan dengan matapencaharian. Kemudian data hasil identifikasi tersebut dianalisis secara deskriptif kualitatif yang bertujuan untuk memahami makna atau menafsirkan realitas empiris yang terkandung pada objek-objek kajian (Gede, 2013:183). Dalam tahap analisis ini meliputi analisis artefak dan analsis lingkungan sekitar situs.

\section{HASIL DAN PEMBAHASAN}

Eksplorasi arkeologi di situs Gunung Srobu telah menemukan sejumlah besar materi budaya masa lampau yang diindikasikan berhubungan dengan sistem matapencaharian hidup manusia pendukungnya. Temuan materi-materi budaya yang kehadiran sebagai bukti aktivitas manusia masa lampau dalam usaha pemenuhan kebutuhan hidupnya, berupa artefak gerabah, alat-alat batu, alat kerang, sisa tulang binatang, dan sampah kerang,

Selain tinggalan budaya, bentang alam juga merupakan data penting yang berguna untuk menggambarkan, menjelaskan, serta memahami tingkah laku maupun interaksi manusia dengan lingkungannya. Misalnya, bagaimana manusia berkreasi dalam menghadapi tantangan alam serta lingkungannya dan keluwesannya dalam beradaptasi telah berhasil menaklukkan lingkungan serta mampu memanfaatkannya untuk memenuhi segala kebutuhan hidupnya (Prasetyo dkk., 2004 :21). Hal ini tidak terlepas dari keadaan lingkungan hidup manusia yang juga ditempati benda-benda lain, baik yang bersifat hidup maupun tak hidup (Soemarwoto, 2004: 48-49) yang kesemuanya saling pengaruh-mempengaruhi. Manusia dalam hubungan dengan alam sekitar tidak hanya saling ketergantungan semata, melainkan terwujud dalam bentuk hubungan yang saling mempengaruhi dan mampu merubah lingkungan tersebut yang dijembatani oleh pola-pola kebudayaan yang dimilikinya (Purwanto, 2008: 166).

Dalam kaitan dengan hal tersebut di atas, maka bagaimana dengan tinggalan budaya masa lampau masyarakat pendukung budaya situs Gunung Srobu dapat mengungkapkan tentang bentuk-bentuk matapencahariannya. Untuk itu perlu dicermati terlebih 
dahulu bahwa dalam berbagai macam aktivitas manusia zaman dahulu yang sebagian besar berhubungan dengan pemenuhan kebutuhan hidupnya akan makanan, dan bahkan dapat digolonggolongkan ke dalam suatu perangkat sistem matapencaharian. Para ahli antropologi membagi aktivitas ke dalam tahapan-tahapan yang mendasar bagi sistem ini, antara lain: berburu dan meramu, beternak, perladangan, nelayan, pertanian, dan industri. Pada umumnya, setiap bentuk tahapan tersebut menandakan suatu bentuk masyarakat. Meskipun demikian, ada kemungkinan suatu masyarakat dapat melakukan dua atau tiga tahap aktivitas tersebut sekaligus (NN, 2003: 31).

Dalam mengungkapkan bentuk matapencaharian masyarakat pendukung situs Gunung Srobu dapat dilakukan melalui kajian terhadap sisasisa kehidupannya yang terawetkan. Dalam kajian ini akan diawali dengan mengidentifikasi bentuk-bentuk materi budaya yang dapat dikaitkan dengan bentuk matapencahariannya. Bentuk materi budaya dapat berupa artefak tembikar, kapak batu, alat serpih, kapak lonjong, gandik, pipisan, alat batu penokok, alat batu, alat kerang, sisa tulang binatang, dan sampah kerang yang keberadaannya melingkupi seluruh permukaan situs dan telah membukit.

Kajian pada keberadaan materimateri budaya tersebut dipandang mampu menjelaskan tentang bentukbentuk matapencaharian masyarakat pendukung situs Gunung Srobu. Di samping itu, juga dilakukan kajian pada potensi lingkungan alam sekitarnya yang merupakan data penting yang mendukung untuk mengungkapkan bentuk-bentuk mata pencaharian masyarakat pendukung situs Gunung Srobu, yang mana lingkungan alam merupakan faktor utama pendorong terbentuknya suatu matapencaharian.

Dari perspektif arkeologi, artefak dapat menunjukkan suatu bentuk matapencaharaian. Demikian halnya temuan-temuan artefak di situs Gunung Srobu dapat menggambarkan bahwa ada beberapa bentuk matapencaharian masyarakat pendukungnya. Misalnya, temuan artefak gerabah yang sudah dikenal manusia sejak munculnya budaya bercocoktanam di daerah pedalaman dan budaya mencari hasil laut di daerah pantai (Gardner, 1978: 142, Weinhold, 1983: 12, dalam Sriwigati, 2007: 25). Kehadiran artefak gerabah juga menunjukkan suatu bentuk teknologi yang dihasilkan pada zaman neolitik dan terus berkembang hingga kini. Pernyataan ini sangat mendukung keberadaan situs Gunung Srobu sebagai situs yang berciri budaya neolitik, dan bahkan berdasarkan hasil pertanggalan Radiocarbon Dating (C14) menunjukkan bahwa situs ini berumur $2280 \pm 150$ B.P yaitu masuk ke dalam kurun waktu neolitik akhir (Tim Peneliti, 2014: 50).

Sehubungan dengan hal tersebut dapat dikatakan bahwa manusia pendukung budaya situs Gunung Srobu juga sudah melakukan aktivitas bercocoktanam maupun mencari hasil laut, hal ini terlihat dari bentuk-bentuk tinggalan budayanya dan juga didukung pula oleh lingkungan alam sekitarnya, dan mencari hasil laut merupakan 
matapencaharian utamanya, hal ini didukung oleh posisi situs yang berada di pesisir pantai dan di atas sebuah tanjung.

Sebelum diuraikan lebih jauh tentang bentuk-bentuk matapencaharian masyarakat pendukung situs Gunung Srobu, terlebih dahulu akan dibahas tentang materi-materi budaya yang ditemukan di situs tersebut. Indikasi terkait dengan aktivitas matapencaharian, yaitu seperti gerabah, alat batu (yang meliputi alat masif, alat serpih, kapak lonjong, batu penokok, batu penumbuk atau gandik, batu pipisan, bandul jala, mata panah, dan gurdi), alat kerang, sampah tulang binatang dan sampah kerang. Ditinjau dari bentuk dan fungsi materi-materi budaya tersebut tergambar dengan jelas bahwa ada beberapa bentuk matapencaharian masyarakat pendukungnya. Selain itu, terlihat pula bahwa satu artefak dapat digunakan dalam beberapa aktivitas matapencaharian.

Temuan artefak gerabah misalnya, kehadirannya sangat identik dengan periode bercocoktanam (neolitik). Pada masa itu, manusia memiliki banyak waktu luang untuk menghasilkan wadah tersebut dan ditunjang oleh tingkat pengetahuannya. Dari fungsinya, gerabah terkait erat sebagai wadah untuk menyimpan, mengolah dan menyajikan makanan, namun pada perkembangannya wadah tersebut juga difungsikan sebagai sarana upacara, bekal kubur dan bahkan sebagai wadah kubur. Gerabah dalam fungsinya pada aktivitas bercocoktanam lebih kepada alat menyimpan dan mengolah makanan. Penggunaan wadah ini, juga ditunjang peralatan lainnya, seperti alat batu. Secara umum, wadah gerabah terkait erat dengan semua jenis aktivitas matapencaharian, karena didukung oleh fungsi atau kegunaannya sebagai alat menyimpan makanan.

Artefak alat batu yang ditemukan berhubungan dengan aktivitas manusia di situs Gunung Srobu. Alat batu sebagaimana gerabah juga menggambarkan berbagai aktivitas manusia, misalnya kapak batu, kapak lonjong, alat serpih, batu penokok, mata panah, batu pipisan dan gandik, serta alat gurdi dan batu asah. Temuantemuan tersebut merupakan alat bantu bagi manusia untuk memudahkan dalam melakukan aktivitas matapencaharian hidupnya. Misalnya kapak batu, kapak lonjong dan alat serpih yang kehadiran erat kaitannya dengan usaha pemenuhan kebutuhan peralatan untuk memotong, menebang, membelah, menguliti, dan menyerut. Berdasarkan fungsinya, peralatan batu tersebut kehadirannya sangat erat kaitannya dengan aktivitas bercocoktanam, meramu dan berburu. Dalam aktivitas bercocoktanam, kapak batu digunakan sebagai alat untuk menebang pohon, sedangkan kapak lonjong lebih pada fungsi memotong dan membelah kayu. Fungsi alat batu dalam aktivitas bercocoktanam adalah terkait dengan pembukaan lahan dan pembuatan pagar, seperti terlihat pada beberapa kelompok masyarakat yang berada di pegunungan tengah Papua. Sementara untuk alat serpih juga terkait dengan semua jenis aktivitas matapencaharian terutama pada fungsinya sebagai alat 

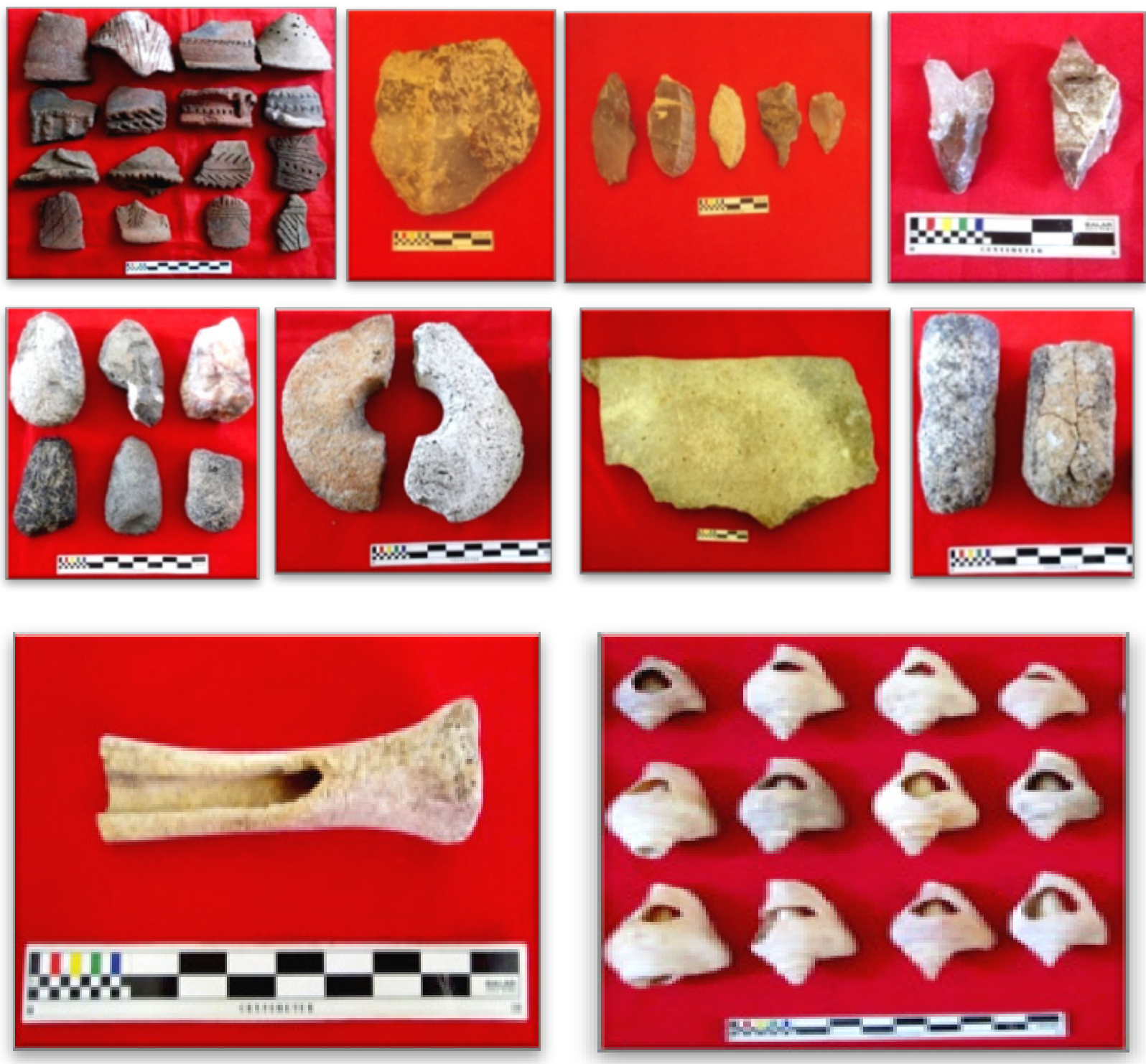

Gambar 1. Temuan artefak situs Gunung Srobu; fragmen gerabah, kapak batu, mata panah, kapak lonjong, pemberat jaring dari batu, batu penokok, alat kerang, batu pipisan, dan fragmen alat tulang (Dokumentasi Balai Arkeologi Jayapura)

untuk memotong, menguliti, mengiris, maupun menyerut. Sedangkan dalam kaitannya dengan aktivitas meramu, kapak batu digunakan untuk menebang pohon sagu; kapak lonjong untuk memotong dan membelah batang sagu sebelum ditokok. Dalam aktivitas menokok sagu tersebut juga menggunakan alat batu penokok dan mungkin juga menggunakan kapak lonjong. Asumsi penggunaan kapak lonjong sebagai alat penokok muncul, karena pada masyarakat suku terasing --- diantaranya suku Korowai dan suku Kombai --- masih melakukan aktivitas menokok sagu dengan menggunakan kapak lonjong, yaitu bagian pangkalnya untuk menokok, sedangkan bagian ujung untuk memotong dan membelah batang pohon sagu (Kawer, 2014: 13). Terkait dengan aktivitas meramu sagu tersebut didukung pula oleh potensi lingkungan alam kawasan sekitar situs Gunung Srobu yang terdapat beberapa 
tempat lahan sagu yang sangat luas, namun saat ini lahan-lahan tersebut telah berubah menjadi area permukiman padat penduduk.

Sedangkan asumsi tentang pemanfaatan kapak batu untuk kegiatan berburu dipengaruhi oleh masih terlihatnya pemanfaatkan kapak batu dalam suatu aktivitas perburuan pada beberapa masyarakat suku di pegunungan tengah Papua. Selain untu berburu, suku pegunungan tengah bahkan menggunakan kapak batu sebagai alat perang dan sarana upacara. Selain kapak batu, kehadiran mata panah juga diidentikan dengan aktivitas berburu. Aktivitas berburu juga merupakan salah satu matapencaharian masyarakat pendukung budaya situs Gunung Srobu. Aktivitas berburu selain didukung temuan peralatan perburuan, juga ditegaskan pula oleh keberadaan temuan sisa-sisa tulang binatang. Aktivitas ini juga didukung oleh potensi lingkungan sekitar situs yang mendukung akan kehadiran binatangbinatang buruan, seperti babi hutan, walabi/ kuskus, tikus tanah, beberapa jenis burung dan lainnya.

Temuan alat batu lainnya adalah berupa batu pipisan dan gandik, yaitu dua jenis artefak yang memiliki hubungan saling menunjang. Kehadiran artefak ini lebih dikaitkan pada fungsinya dalam mengolah makanan dan rempah-rempah, baik untuk melumatkan maupun menghaluskan. Sedangkan untuk alat bor/gurdi dan batu asah lebih sebagai peralatan penunjang produksi peralatan. Batu asah berfungsi untuk menghaluskan permukaan kapak batu dan alat lainnya, sedangkan alat gurdi lebih difungsikan untuk melubangi suatu alat seperti dalam pembuatan alat kerang, pembuatan perhiasan manik-manik dan mungkin juga untuk melubangi kayu atau bahan kulit kayu atau daun yang digunakan untuk memenuhi kebutuhan akan pakaian, namun karena bahan kulit kayu atau daun mudah hancur termakan usia maka tidak dapat ditemukan sisa-sisanya. Asumsi ini muncul karena pada beberapa suku di kawasan pesisir pantai Papua telah mengenal pemanfaatan kulit kayu dan daun sebagai pakaian maupun untuk kegunaan lainnya.

Mengacu pada berbagai jenis temuan artefak batu seperti kapak batu, alat serpih, batu penokok, mata panah dan gurdi, diperkirakan bahwa benda-benda tersebut diproduksi oleh masyarakat pendukung budaya Situs Gunung Srobu. Pandangan ini muncul dikarenakan selain ditemukan artefak batu, juga disertai temuan sejumlah calon alat, batu inti dan limbah produksi batuan, serta diketahui lokasi sumber bahan baku alat batu yang diambil dari lingkungan di kawasan sekitar situs. Aktivitas produksi alat pada situs Gunung Srobu juga didukung oleh kehadiran beberapa alat batu lainnya yang fungsinya sebagai penunjang dalam proses peciptaan suatu alat batu, seperti kehadiran perkutor dan batu asah.

Aktivitas mata pencaharian lainnya yang menjadi aktivitas utama masyarakat pendukung situs Gunung Srobu adalah aktivitas mengambil hasil laut atau nelayan yaitu tergambar dari kehadiran artefak kerang dan artefak 
batu berbentuk cincin elips besar (mace head) yang dijadikan sebagai alat pemberat jaring untuk menangkap ikan, dan untuk pemanfaatan alat kerang masih dapat disaksikan pada masyarakat nelayan yang berada di Kepulauan Padaido, yang hingga kini masih memanfaatkan cangkangcangkang kerang sebagai alat yang diikatkan pada ujung-ujung jaring di semua sisi yang berfungsi sebagai pemberat saat ditebarkan ke dalam air ketika menjaring. Kalau di Kepulauan Padaido memanfaatkan jenis kerang cipraedae, sedangkan di situs Gunung Srobu menggunakan jenis kerang strombidae dan cipraedae. Dalam hubungannya dengan aktivitas mencari ikan tersebut, selain temuan alat kerang juga didukung pula oleh temuan sisasisa tulang ikan (Tim Peneliti, 2014: 47). Selain menangkap ikan, mereka juga mengumpulkan kerang sebagai sumber makanan, kenyataan ini didukung oleh temuan sampah kerang yang telah membukit, selain itu kondisi ini didukung oleh keadaan lingkungan alam laut sekitar situs di kawasan teluk Youtefa yang sangat berpotensi akan kandung kerang lautnya, dan selain itu juga terdapat area-area bakau dengan potensi kepitingnya serta potensi lautan yang menyediakan banyak biota laut lainnya seperti ikan, gurita, suntung, cumi-cumi dan lainnya. Potensi-potensi laut tersebut merupakan sumber makanan utama bagi masyarakat pendukung situs Gunung Srobu dan ini juga ditunjang oleh posisi situs yang berada di pesisir pantai yaitu di atas sebuah tanjung, hal ini sejalan dengan pandangan bahwa masyarakat yang bertempat tinggal di tepi pantai hidupnya lebih bergantung pada bahanbahan makanan yang terdapat di laut (Soejono dan Leirissa, 2010: 141).

Aktivitas matapencaharian lainnya yang juga dilakukan adalah beternak. Aktivitas beternak muncul ketika manusia telah hidup menetap dalam suatu perkampungan dan telah mampu membagi waktu dalam melakukan berbagai aktivitasnya. Aktivitas beternak pada masyarakat pendukung situs Gunung Srobu didukung oleh temuan sisa-sisa tulang babi. Pandangan ini muncul karena babi merupakan salah satu jenis binatang liar yang mudah dijinakkan dan tidak sulit dalam memeliharaannya serta tidak membutuhkan waktu dan tenaga yang banyak. Pola beternak babi zaman dahulu dapat dilihat gambarannya pada polanya pada beberapa kelompok masyarakat tradisional di Papua saat ini, yaitu binatang babi yang didapat dari hasil perburuan kemudian dijinakkan dalam sebuah kandang; dan setelah babi tersebut jinak maka dilepas untuk mencari makanannya sendiri, tetapi juga pada waktu-waktu tertentu diberi makan oleh pemiliknya.

Terkait dengan berbagai bentuk aktivitas matapencaharian tersebut, tergambar pula tentang pola kehidupan masyarakat pendukung situs yang telah hidup menetap dalam suatu permukiman. Mereka bahkan telah memiliki cukup banyak waktu untuk melakukan berbagai aktivitas, seperti terbukti dari munculnya berbagai bentuk matapencaharian yang tercermin pada tinggalan budayanya, dan didukung pula oleh potensi lingkungan alam sekitarnya. Hal ini juga menunjukkan bahwa masyarakat pendukung situs 
Gunung Srobu telah berada pada suatu kondisi masyarakat yang terstruktur dan terorganisir dengan baik serta juga telah ada pembagian tugas yang jelas antara laki-laki dan perempuan, keadaan ini masih dapat disaksikan pada masyarakat-masyarakat adat di Papua hingga sekarang.

\section{PENUTUP}

Berdasarkan hasil pembahasan tentang bentuk-bentuk

matapencaharian masyarakat pendukung budaya Situs Gunung Srobu, terungkap dengan jelas bahwa ada beberapa macam bentuk matapencahariannya seperti nelayan/mengumpulkan hasil laut, bercocoktanam, meramu, berburu, beternak, dan industri. Bentuk-bentuk matapencaharian tersebut terungkap berdasarkan kajian pada materi budaya sisa-sisa aktivitas manusia, dan juga kajian terhadap keadaan kondisi lingkungan alam sekitar situs, yang dipandang sebagai faktor utama sehingga terbentuknya berbagai bentuk matapencaharian tersebut. Dari semua jenis matapencaharian yang ada, nelayan atau mengumpulkan hasil laut merupakan matapencaharian utamanya. Di samping itu, kehadiran beragam bentuk matapencaharian pada masyarakat pendukung Situs Gunung Srobu ini, didukung pula oleh potensi manusia pendukungnya yang telah memiliki tingkat pengetahuan maupun tingkat penguasaan teknologi yang maju, sehingga dapat mendorong mereka untuk melakukan berbagai macam aktivitas hidup. 


\section{DAFTAR PUSTAKA}

Gede, I Dewa Kompyang. 2013."Misba Dalam Masyarakat Alor: Kajian Bentuk dan Fungsi”, dalam Forum Arkeologi Volume 26, Nomor 3, November 2013. Denpasar: Balai Arkeologi Denpasar, Kementerian Pendidikan dan Kebudayaan, HIm. 181-194.

Kawer, Sonya Martha. 2014. "Eksplorasi Arkeologi di Distrik Bomakia Kabupaten Boven Digoel", dalam Berita Penelitian Arkeologi No.12. Jayapura: Balai Arkeologi Jayapura, Kementerian Pendidikan dan Kebudayaan, HIm. 1- 41.

NN. 2003. "Ensiklopedia Suku Bangsa Mentawai". Jakarta: Kementerian Kebudayaan dan Pariwisata. Deputi Bidang Nilai Budaya, Seni dan Film. Proyek Pengembangan Kebijakan Nilai Budaya, Seni dan Film.

Prasetyo, Bagyo, D.D. Bintarti, Dwiyani Yuniawati, E. A. Kosasih, Jatmiko, Retno Handini, E. Wahyu Saptomo. 2004. Religi pada Masyarakat Prasejarah di Indonesia. Jakarta: Kementerian Kebudayaan dan Pariwisata. Proyek Penelitian dan Pengembangan Arkeologi.

Purwanto, Hari. 2008. Kebudayaan dan Lingkungan dalam Perspektif Antropologi. Yogyakarta: Pustaka Pelajar.

Soejono, R. P. dan R. Z Leirissa (Ed.). 2010. Sejarah Nasional Indonesia I. Zaman Prasejarah di Indonesia. Edisi Pemutakhiran. Jakarta: Balai Pustaka.

Soemarwoto, Otto. 2004. Ekologi Lingkungan Hidup dan Pembangunan. Jakarta: Penerbit Djambatan.

Sriwigati. 2007."Hiasan Gerabah dari Situs Gua Buida”, dalam Haris Sukendar (Ed.), Jejak-Jejak Arkeologi di Sulawesi Utara, Gorontalo, Sulawesi Tengah dan Daerah Lainnya. Balai Arkeologi Manado bekerjasama dengan IAAI Komda Sulawesi, Maluku dan Irian. HIm. 25-33.

Tim Peneliti. 2014. "Eksplorasi Arkeologi di Situs Gunung Srobu, Kelurahan Abe Pantai, Distrik Abepura. Kota Jayapura". Laporan Penelitian Arkeologi. Balai Arkeologi Jayapura.

Vita. 2004. "Faktor-Faktor Lingkungan Yang Mempengaruhi Kelangsungan Hidup Manusia Purba pada Masa Holosen di Gua-Gua Situs Sampung, Provinsi Jawa Timur" dalam Lingkungan Masa Lampau Beberapa Situs Arkeologi di Jawa Timur dan Bali. Jakarta: Kementerian Kebudayaan dan Pariwisata. Proyek Penelitian dan Pengembangan Arkeologi. HIm. 25-47.

\section{INTERNET}

http://pusatbahasa.kemdiknas.go.id/kbbi/ Kamus Besar Bahasa Indonesia V1.3. 2010-2011. 